\title{
ЄВРОПЕЙСЬКІ СТАНДАРТИ У СФЕРІ ЗАХИСТУ ПРАВ ОСІБ, ПОСТРАЖДАЛИХ ВІД НЕЗАКОННИХ РІШЕНЬ, ДІЙ ЧИ БЕЗДІЯЛЬНОСТІ В МЕЖАХ КРИМІНАЛЬНОГО ПРОЦЕСУ
}

Постановка проблеми. Процеси глобалізації, які зараз відбуваються у всьому світі, зумовили зближення правових систем та впливають на реформування національної правової системи України. Нині відбувається імплементація міжнародних стандартів до правових систем окремої держави. Цей процес не оминув і нашу державу.

Слід зазначити, що на рівні міжнародних угод єдиного визначення понять «міжнародні стандарти прав людини» i «стандарти захисту прав осіб, потерпілих від кримінальних правопорушень» немає, як і не містить їх чинне законодавство України. В юридичній літературі поняття «міжнародні стандарти захисту прав людини» нерідко ототожнюється 3 правами особи або із зобов'язаннями держав-учасниць за міжнародними договорами, або з принципами міжнародного права [1, с. 9].

Великий тлумачний словник сучасної української мови визначає стандарти як норму, зразок, мірило [2, с. 1187]. Енциклопедична література визначає міжнародно-правові стандарти як норми та принципи, що закріплюють стандартизовані правила поведінки суб'єктів міжнародного права у тих чи інших сферах міжнародного права [3, с. 615]. Науковці визначають міжнародно-правові стандарти як закріплені у нормах міжнародного права або сформульовані в рішеннях міжнародних судових установ, визнані міжнародною спільнотою мінімальні вимоги, що мають імперативний або рекомендаційний характер для держави і визначають вектор розвитку національного законодавства [4, с. 91].

Сьогодні, коли стає помітним значний вплив норм міжнародного права на внутрішнє законодавство кожної країни, є всі підстави вважати правовою ту державу, яка у своїй правовій системі повною мірою використовує потенціал міжнародних норм [5, с. 59-61]. Саме тому особливого значення набуває визначення європейських стандартів у сфері захисту прав осіб, постраждалих від незаконних рішень, дій чи бездіяльності в межах кримінального процесу.

Оцінка стану літератури. Процесуальний порядок відшкодування шкоди, заподіяної протиправним притягненням особи до кримінальної відповідальності (засудженням) став предметом наукового дослідження О.В. Капліної у роботі «Проблеми реабілітації у кримінальному процесі України» [6]. Одним із напрямів наукових досліджень М.Є Шуміло стало питання реабілітації у кримінальному процесі України [7]. Питаннями реалізації європейських стандартів у кримінальному провадження займаються О.М. Дроздов [8], М.Г. Моторигіна [4] та інші вчені. Незважаючи на грунтовні дослідження науковців, нині залишається недослідженим питання 
європейських стандартів у сфері захисту прав осіб, постраждалих від незаконних рішень, дій чи бездіяльності у кримінальному процесі.

Метою статті є визначення європейських стандартів у сфері захисту прав осіб, постраждалих від незаконних рішень, дій чи бездіяльності в межах кримінального процесу.

Виклад основного матеріалу. Слід визнати, що провідну роль у створенні міжнародно-правових стандартів відіграє Конвенція про захист прав людини і основоположних свобод (далі - КЗПЛ), а також установа, яка розглядає скарги на порушення КЗПЛ, а саме Європейський суд з прав людини (далі - ЄСПЛ). 3 огляду на положення ч. 5 ст. 9 КПК України, де зазначається, що кримінальне процесуальне законодавство України застосовується 3 урахуванням практики ЄСПЛ, а також процеси євроінтеграції України особливого значення набувають міжнародно-правові стандарти, які формуються КЗПЛ та ЄСПЛ.

Ратифікація ВР України КЗПЛ у 1997 р. означає обов'язок України дотримуватися КЗПЛ, норми якої перебувають в органічній єдності з рішеннями ЄСПЛ, а їх практичне втілення відбувається в законодавчих i правозастосовних внутрішньодержавних заходах [4, с. 94].

Суди задля забезпечення єдності судової практики, зокрема щодо їі відповідності міжнародним стандартам, здійснюючи правосуддя, разом із нормами національного законодавства мають застосовувати норми Конвенції. Оскільки у КЗПЛ є низка характерних особливостей, ї̈ положення мають загальний характер, а права людини здебільшого констатуються у ній в абстрактній, оціночній формі, правильне розуміння ї норм розкривається у рішеннях ЄСПЛ, які містять правові позиції щодо сутності положень зазначеного міжнародно-правового акта, а також змісту та обсягу гарантованих ним прав [9]. Ці стандарти стосуються постраждалих від арешту або затримання; від незаконного засудження.

КЗПЛ проголошує, що «кожен, хто $€$ потерпілим від арешту або затримання на порушення положень цієї статті, має захищене позовом право на відшкодування» (ч. 5 ст. 5).

Стаття 3 Протоколу № 7, яка має назву «Відшкодування в разі незаконного засудження», закріплює положення, відповідно до якого «якщо остаточним рішенням особу було засуджено за вчинення кримінального правопорушення і якщо винесений ій вирок було потім скасовано або ї̈ було помилувано на підставі нового чи нововиявленого факту, який беззаперечно доводить наявність судової помилки, то ця особа, яка зазнала покарання в результаті такого засудження, одержує відшкодування згідно із законом або практикою відповідної держави, якщо тільки не буде доведено, що зазначений невідомий факт не було свого часу виявлено повністю або частково 3 вини цієї особи».

Аналогічна норма викладена в Міжнародному пакті про громадянські і політичні права (далі - МПГПП), де зазначено таке: «коли будь-яку особу остаточним рішенням було засуджено за кримінальний злочин і коли винесений їй вирок був потім скасований або їй було даровано помилування на тій підставі, що якась нова чи нововиявлена обставина незаперечно доводить наявність судової помилки, то ця особа, котра зазнала покарання в результаті такого засудження, одержує компенсацію згідно з законом, коли не буде доведено, що зазначена невідома обставина не була свого часу виявлена виключно або частково з їі вини. Ніхто не повинен бути вдруге засуджений чи покараний за злочин, за який він уже був остаточно засуджений або виправданий відповідно до закону і кримінально-процесуального права кожної країни» (п. п. 6, 7 ст. 14) [10].

Щодо внутрішньо національного закріплення відшкодування шкоди, 
завданої незаконними рішеннями, діями чи бездіяльності органу, що здійснює оперативно-розшукову діяльність, досудове розслідування, прокуратури або суду, слід зазначити, що підлягає відшкодуванню шкода, завдана громадянинові внаслідок незаконного засудження, незаконного повідомлення про підозру у вчиненні кримінального правопорушення, незаконного взяття і тримання під вартою, незаконного проведення в ході кримінального провадження обшуку, виїмки, незаконного накладення арешту на майно, незаконного відсторонення від роботи (посади) та інших процесуальних дій, що обмежують права громадян (п. 1 ст. 1 ЗУ «Про порядок відшкодування шкоди, завданої громадянинові незаконними діями органів, що здійснюють оперативно-розшукову діяльність, органів досудового розслідування, прокуратури і суду») [11].

Розпочинаючи дослідження практики ЄСПЛ, пропонуємо звернутися до тлумачення ч. 5 ст. 5 КЗПЛ, де зазначається, що кожен, хто є потерпілим від арешту або затримання на порушення положень цієї статті, має захищене позовом право на відшкодування. В розумінні національного законодавства (п. 1 ст. 1 ЗУ «Про порядок відшкодування шкоди, завданої громадянинові незаконними діями органів, що здійснюють оперативно-розшукову діяльність, органів досудового розслідування, прокуратури і суду») відшкодування шкоди, за ч. 5 ст. 5 КЗПЛ, належить до сфери захисту прав осіб, постраждалих від незаконного рішення, дії чи бездіяльності органу, що здійснює оперативно-розшукову діяльність, досудове розслідування, прокуратури або суду.

Цікаво відзначити, що під час роз'яснення положень ст. 5 КЗПЛ ЄСПЛ активно оперує терміном «стандарт статті 5». Так, ЄСПЛ вказав на те, що примусове перебування особи в психіатричній лікарні є позбавленням свободи і має оцінюватись за стандартами ст. 5 (справа «Вінтерверп проти Нідерландів» (1979 р.) [12]); ЄСПЛ робить висновок про неможливість застосування стандартів ст. 5 до ситуації поміщення ув'язненого в дисциплінарний ізолятор, оскільки це лише зміни режиму тримання під вартою (справа «Боллан проти Об'єднаного королівства» [13]).

Важливо зазначити, що право на відшкодування в розумінні ч. 5 ст. 5 КЗПЛ виникає виключно на підставі порушення п. п. 1-4 ст. 5 КЗПЛ. Такого висновку дійшов ЄСПЛ у своєму рішенні «Солдук проти Туреччини». Так, ЄСПЛ нагадує, що, відповідно до п. 5 ст. 5 (ст. 5-5) КЗПЛ, право на компенсацію за будь-які матеріальні чи моральні збитки, заподіяні в результаті затримання, мають бути явно обумовлені порушенням одного 3 пунктів ст. 5. Комісія не може розглядати позов заявника виключно на підставі п. 5 ст. 5, якщо не порушено п. п. 1-4 ст. 5 [14].

На підтвердження цього твердження можна навести рішення ЄСПЛ, у яких питання про відшкодування шкоди вирішується за умови порушення п. п. 1-4 ст. 5 КЗПЛ. Так, у рішенні «Хамроєв і інші проти України» ЄСПЛ установив порушення п. 1 ст. 5 стосовно Хамроєва через незаконність його утримання під вартою з 15 по 24 червня 2010 р., порушення п. 1 ст. 5 стосовно Хамроєва, Дадаханова і Акрамова щодо нездатності національної влади провести провадження про їх екстрадицію 3 належною ретельністю після 22 листопада 2010 р. У зв’язку зі встановленням зазначених порушень ЄСПЛ призначив Хромаєву, Дадаханову і Акрамову відшкодування шкоди за П. 5 ст. 5 КЗПЛ, а саме 10000 євро кожному [15, с. 160-162].

У справі «Васілікіук проти Республіка Молдова» ЄСПЛ установив, що нездатність влади зробити обгрунтовані спроби проінформувати заявника про відкриття кримінального провадження проти неї і необхідність 
постати перед нею становить порушення КЗПЛ. Відмова національних судів перевірити твердження заявника про невідповідний виклик та надати ій можливість постати перед владою переконала Суд у тому, що утримання заявника під вартою неможливо було вважати необхідним і позбавленим свавілля. У зв'язку з цим ЄСПЛ визнав порушення п. 1 ст. 5 КЗПЛ i, відповідно до п. 5 ст. 5, призначив компенсацію у розмірі 3000 євро [15, c. 169-170].

У справі «Летельє проти Франціï ЄСПЛ встановив порушення ст. 5 п. 3 КЗПЛ (щодо відсутності підстав тримання особи під вартою) і призначив відшкодування шкоди за п. 5 ст. 5 КЗПЛ [15, с. 132-138].

Продовжуючи дослідження, звертаємося до тлумачення ст. 3 Протоколу № 7 «Відшкодування в разі незаконного засудження», яке здійснюється ЄСПЛ у його рішеннях.

У справі «Шиляєв проти Російської Федерації» ЄСПЛ нагадав, що положення ст. 3 Протоколу 7 передбачають право на компенсацію особам, які позбавлені волі як порушення одного з пунктів ст. 5 КЗПЛ, а також право на компенсацію за судову помилку, коли заявник був визнаний винним у скоєнні злочину остаточним рішенням суду й піддався відповідному покаранню. Положення КЗПЛ, однак, не перешкоджають договірним державам присуджувати компенсацію залежно від можливості особи, яка постраждала, довести наявність шкоди, заподіяної ій відповідним порушенням; Конвенція також не встановлює будь-яких конкретних розмірів компенсації (п. 20) [16].

У справі «Матвєев проти Російської Федерації» ЄСПЛ визначає, що ст. 3 Протоколу № 7 встановлює, що компенсація жертві судової помилки виплачується на певних умовах. По-перше, зацікавлена особа мала бути засуджена за вчинення кримінального злочину на підставі остаточного вироку і має понести покарання в результаті такого засудження. Згідно з визначенням, що міститься в пояснювальній доповіді до КЗПЛ про міжнародне визнання судових рішень у кримінальних справах, вирок є остаточним, «якщо з використанням традиційного виразу він набув сили res judicata» (res judicata - принцип остаточності рішень суду). Справа вважається такою, якщо рішення $€$ незаперечним, тобто ніякі звичайні засоби правового захисту недоступні або сторони вичерпали такі засоби чи протягом строків давності не скористалися ними. Таким чином, вирок за замовчуванням не вважається остаточним, поки національне законодавство допускає відновлення розгляду. Аналогічно ця стаття не застосовується у справах, у яких обвинувачення знімається або обвинувачений виправданий судом першої інстанції або за скаргою вищим судом». По-друге, стаття застосовується, тільки якщо винесений особі обвинувальний вирок був скасований або іiі було помилувано в будь-якому разі на тій підставі, що будь-яка нова або нововиявлена обставина беззаперечно доводить, що наявна судова помилка, тобто якийсь серйозний дефект судочинства, який заподіяв істотну шкоду засудженому. Таким чином, стаття не містить вимоги про виплату компенсації, якщо винесений вирок скасовується або застосовується помилування 3 якоїсь іншої підстави. Стаття також не має на меті встановлення будь-яких правил щодо характеру процедури, яка застосовується для встановлення судової помилки. Це питання національного законодавства або практики зацікавленої держави. Слова «або іiі було помилувано» використані, оскільки в деяких правових системах належним засобом правового захисту після винесення остаточного вироку в певних справах є помилування, а не розгляд, який тягне скасування обвинувального вироку. По-третє, право на компенсацію, відповідно до цього 
положення, не виникає, якщо буде доведено, що невідомий раніше факт не було свого часу виявлено повністю або частково з вини засудженого (п. 22) [17].

У справі «Наков проти Македоніі» ЕСПЛ зазначає, що право на компенсацію гарантується лише тоді, коли особа була засуджена за кримінальне правопорушення остаточним рішенням. До того ж у цій справі заявник ніколи не притягувався до судового розгляду і ніколи не був засуджений [18].

Щодо остаточності судового рішення у зв'язку 3 вичерпанням засобів національного захисту ЄСПЛ у справі «Свіргунець проти України» зазначає, що мета правила вичерпання національних засобів юридичного захисту за ст. 35 КЗПЛ полягає в наданні договірним державам можливості запобігти порушенню, у зв'язку 3 яким проти них подано скаргу, чи виправити такі порушення ще до того, як скарги будуть подані до Конвенційних установ. При цьому зазначене правило має застосовуватися з певною гнучкістю і без зайвого формалізму. Суд уже неодноразово встановлював, що це правило не $є$ ані абсолютним, ані таким, що застосовується автоматично; щоби перевірити, чи було воно дотримане, необхідно брати до уваги обставини конкретної справи. Зокрема, Суд звертає увагу на те, чи зробив заявник усе, чого можна було обгрунтовано очікувати, для вичерпання доступних національних засобів юридичного захисту (п. 67) [19].

У наведених вище рішеннях неодноразово згадувався принцип res judicata. Пропонуємо зупинитися на цьому питанні. Так, у доповіді Венеційської комісії «Верховенство права» вказується на те, що юридична визначеність вимагає дотримання принципу res judicata. Остаточні рішення судів національної системи не мають бути предметом оскарження. Юридична визначеність також вимагає, щоб остаточні рішення судів були виконані. Системи, де існує можли- вість скасовувати остаточні рішення, не базуючись на безспірних підставах публічного інтересу, та які допускають невизначеність у часі, несумісні з принципом юридичної визначеності. Нарешті, судові рішення мають бути ефективно виконані і не мають існувати можливості (окрім надзвичайно виняткових випадків) переглядати остаточне судове рішення [20].

Розвиваючи тезу, зазначимо, що ЄСПЛ у справі «Пономарьов проти України» звертає увагу на те, що «право на справедливий розгляд судом, яке гарантовано п. 1 ст. 6 КЗПЛ, має розумітися у зв'язку з преамбулою Конвенції, у відповідній частині якої зазначено, що верховенство права $є$ спільною спадщиною Високих Договірних Сторін. Одним із фундаментальних аспектів верховенства права $€$ принцип юридичної визначеності, який передбачає повагу до принципу res judicata - принципу остаточності рішень суду. Цей принцип наголошує на тому, що жодна зі сторін не має права вимагати перегляду остаточного та обов'язкового рішення суду просто тому, що вона має на меті добитися нового слухання справи та нового ii вирішення. Повноваження вищих судових органів стосовно перегляду мають реалізовуватися для виправлення судових помилок та недоліків судочинства, але не для здійснення нового судового розгляду. Перегляд не повинен фактично підміняти собою апеляцію, а сама можливість існування двох точок зору на один предмет не $є$ підставою для нового розгляду. Винятки 3 цього принципу можуть мати місце лише за наявності підстав, обумовлених обставинами важливого та вимушеного характеру» (п. 40) [20].

Науковці під час дослідження принципу res judicata доходять висновку, що «ключовими стейкхолдерами дотримання принципу res judicata під час провадження за нововиявленими або виключними обставинами є законодавець та суди» 
[8, с. 866]. Таким чином, принципово важливим для законодавчої конструкції провадження у зв'язку з відшкодуванням шкоди, завданої громадянинові незаконними діями органів, що здійснюють оперативно-розшукову діяльність, органів досудового розслідування, прокуратури і суду, є те, що належна правова процедура має бути встановлена кримінальним процесуальним законом. Такий закон повинен відповідати міжнародно-правовим стандартам. Так, наведені вище норми п. 5 ст. 5 КЗПЛ, Протоколу № 7 та МПГПП, рішення ЄСПЛ, в яких надається тлумачення відповідних норм КЗПЛ, детально визначають умови та порядок відшкодування шкоди в разі незаконного засудження.

Висновки. Беручи до уваги визначення стандартів як норм, зразків, вважаємо, що можна виокремити із зазначених вище норм КЗПЛ та окремих рішень ЄСПЛ стандарти захисту прав засуджених, постраждалих від незаконного рішення, дії чи бездіяльності органу, що здійснює оперативно-розшукову діяльність, досудове розслідування, прокуратури або суду.

1) Відшкодування особі шкоди в разі незаконного засудження $є$ можливим, тільки якщо вона засуджена за вчинення кримінального злочину на підставі остаточного вироку і має понести покарання в результаті такого засудження.

2) Відшкодування особі шкоди в разі незаконного засудження є можливим тільки 3 дотриманням принципу res judicata.

3) Відшкодування особі шкоди в разі незаконного засудження $є$ можливим, тільки якщо винесений особі обвинувальний вирок був скасований або іï було помилувано в будь-якому разі на тій підставі, що будь-яка нова або нововиявлена обставина беззаперечно доводить, що наявна судова помилка.

4) Процедура встановлення судової помилки має вирішуватися виключно на національному рівні.
5) Відшкодування особі шкоди в разі незаконного засудження неможливо, якщо буде доведено, що невідомий раніше факт не було свого часу виявлено повністю або частково з вини засудженого.

6) Право на відшкодування в розумінні ч. 5 ст. 5 КЗПЛ виникає виключно на підставі порушення п. п. 1-4 ст. 5 КЗПЛ.

На нашу думку, лише в разі дотримання наведених вище стандартів захисту прав осіб, постраждалих від незаконного рішення, діï чи бездіяльності органу, що здійснює оперативно-розшукову діяльність, досудове розслідування, прокуратури або суду можна говорити про виконання завдань кримінального провадження, які закріплені у ст. 2 КПК України, зокрема жоден невинуватий не був обвинувачений або засуджений, жодна особа не була піддана необгрунтованому процесуальному примусу, до кожного учасника кримінального провадження застосована належна правова процедура.

У статті досліджено європейські стандарти у сфері захисту прав осіб, постраждалих від незаконних рішень, дій чи бездіяльності в межах кримінального процесу. Проаналізовано норми Конвениії про захист прав людини i основоположних свобод та окремі рішення Європейського суду з прав людини. На основі проведеного аналізу визначено, що стандартами захисту прав засуджених, постраждалих від незаконного рішення, дії чи бездіяльності органу, що здійснюе оперативно-розшукову діяльність, досудове розслідування, прокуратури або суду слід вважати такі: відшкодування особі шкоди в разі незаконного засудження є можливим, тільки якщо вона засуджена за вчинення кримінального злочину на підставі остаточного вироку $i$ має понести покарання в результаті 
такого засудження; відшкодування особі шкоди в разі незаконного засудження є можливим тільки з дотриманням принщипу res judicata; відшкодування особі шкоди в разі незаконного засудження $\epsilon$ можливим, тільки якщо винесений особі обвинувальний вирок був скасований або ї̈ було помилувано в будь-якому випадку на тіü підставі, щзо будь-яка нова або нововиявлена обставина беззаперечно доводить, що наявна судова помилка; прочедура встановлення судової помилки має вирішуватися виключно на національному рівні; відшкодування особі шкоди в разі незаконного засудження неможливо, якщо буде доведено, що невідомий раніше факт не було свого часу виявлено повністю або частково з вини засудженого; право на відикодування в розумінні и. $5 \mathrm{~cm}$. 5 Конвенції про захист прав людини і основоположних свобод виникає виключно на підставі порушення n. n. 1-4 cm. 5 Конвенцї про захист прав людини $i$ основоположних свобод. За результатами проведеного дослідження встановлено, шо лише в разі дотримання наведених вище стандартів захисту прав осіб, постраждалих від незаконного рішення, діі чи бездіяльності органу, що здійснюе оперативно-розшукову діяльність, досудове розслідування, прокуратури або суду можна говорити про виконання завдань кримінального провадження, які закріплені у ст. 2 КПК України, зокрема жоден невинуватий не був обвинувачений або засуджений, жодна особа не була піддана необтрунтованому процесуальному примусу $i$ до кожного учасника кримінального провадження була застосована належна правова процедура.

Ключові слова: відшкодування, засуджений, реабілітація, право, стандарти.

\section{Vyltsan A. European standards} in the field of protection of the rights of persons affected by illegal decisions, actions or inactivity in criminal proceedings

The article examines European standards in the field of protection of the rights of persons affected by illegal decisions, actions or omissions in criminal proceedings. The norms of the Convention for the Protection of Human Rights and Fundamental Freedoms and some decisions of the European Court of Human Rights are analyzed. Based on the analysis, it is determined that the following standards should be considered as standards for protection of the rights of convicts, victims of illegal decision, action or inaction of the body carrying out operative-investigative activity, pre-trial investigation, prosecutor's office or court: 1) only if she has been convicted of a criminal offense on the basis of a final sentence and must be punished as a result of such conviction; 2) compensation to the person in case of illegal conviction is possible only with observance of the principle of res judicata; 3) compensation to a person in case of unlawful conviction is possible only if the conviction was revoked or pardoned in any case on the grounds that any new or newly discovered circumstance unequivocally proves that there is a miscarriage of justice; 4) the procedure for establishing a judicial error should be decided exclusively at the national level; 5) compensation to a person for damage in case of illegal conviction is impossible if it is proved that a previously unknown fact was not revealed in full or in part due to the convict's fault; 6) the right to compensation within the meaning of p. 5 of Art. 5 of the Convention for the Protection of Human Rights and Fundamental Freedoms arise solely on the basis of violation of $p .1-4$ of Art. 5 of Convention for the Protection of Human Rights and Fundamental 
Freedoms. According to the results of the study, it is established that only in compliance with the above standards of protection of the rights of victims of illegal decisions, actions or omissions of the body carrying out investigative activities, pre-trial investigation, prosecution or court can talk about criminal proceedings, which are enshrined in Art. 2 of the CPC of Ukraine, in particular, no innocent person was accused or convicted, no person was subjected to unreasonable procedural coercion and that each participant in criminal proceedings was subject to due process of law.

Key words: compensation, convict, rehabilitation, law, standards.

\section{Лiтература}

1. Демура М.I. Процесуальне становище потерпілого під час досудового розслідування: монографія / наук. ред. B.I. Маринів. Харків : Право, 2018. 224 c.

2. Великий тлумачний словник сучасної украӥнської мови / уклад. і голов. ред. В.T. Бусел. Киів ; Ірпінь : Перун, 2002. C. 1187.

3. Савиук К.О. Стандарти міжнародні. Юридична енциклопедія. Київ, 2003. T. $5: \Pi-C$. C. 615.

4. Моторигіна М.Г. Сторона захисту в судовому провадженні у першій інстаниії : монографія / за наук. ред. О.В. Капліної. Харків : Оберіг, 2018. 306 c.

5. Погребняк С.П. Про деякі проблеми співвідношення між нормами міжнародного права та національного законодавства. Українська державність: становлення, досвід, проблеми : збірник наукових статей (за матеріалами ХІІ Харківських політологічних читань). Харків: Право. 2001. С. 59-61.

6. Капліна О.В. Проблеми реабілітації у кримінальному процесі України: автореф. дис. ... канд. юрид. наук. Харків, 1998. $19 \mathrm{c}$.

7. Шумило М.Е. Реабілітація в кримінальному процесі України : монографія. Харків : Арсіс, 2001. 320 c.

8. Дроздов О.М. Провадження за нововиявленими або виключними обставинами в кримінальному судочинстві за європейськими стандартами. Кримінальний проијесуальний кодекс 2012 року: ідеологія та практика правозастосу- вання : колективна монографія / за заг. ред. Ю.П. Аленіна ; відп. за вип. I.В. Гловюк. Одеса : Видавничий дім «Гельветика», 2018. $1148 \mathrm{c}$.

9. Узагальнення практики застосування статей 3, 5, 6 Конвенції про захист прав людини $i$ основоположнux свобод. URL: https://zib.com.ua/ ua/print/33771-uzagalnennya_praktiki_ zastosuvannya_statey_3_5_6_konvencii_p. html (дата звернення: 30.11.2020).

10. Міжнародний пакт про громадянські $i$ політичні права. URL: https: / / zakon.rada.gov.ua/laws / card/995_043 (даma) звернення: 30.11.2020).

11.Про порядок відшкодування шкоди, завданої громадянинові незаконними діями органів, щз здійснюють оперативно-розшукову діяльність, органів досудового розслідування, прокуратури $i$ суду : Закон України від 13 квітня 2012 р. № 4652-VI. Відомості Верховної Ради України. 1995. № 1. Сm. 1.

12. Biнтерверп проти Hiдерландів: Рішення Європейського суду з прав людини від 24 жовтня 1979 р. URL: https: / / zakon.rada.gov.ua/laws / show/980_155\#Text (даma звернення: 30.11.2020).

13. Боллан проти Об’єднаного королівства : Рішення Європейського суду з прав людини віо 4 травня 2000 р. (заява № 42117/98). URL: http: / / www. associationline.org/guidebook/action/ read/section/jurisprudence / chapter/2/ decision/53 (дата звернення: 30.11.2020).

14. Солдук проти Туреччини : Рішення Європейського суду з прав людини від 16 квітня 1998 p. (заява 31789/96). URL: http: // echr.ketse.com/doc/ 31789.96-en-19980416/view (dama звернення: 30.11.2020).

15. Дроздов О.М., Дроздова О.В. Правові позииіi Європейського суду з прав людини : аналітичний огляд / за заг. ред. М.С. Ковтун, В.I. Ковтуна. Харків : Фактор, 2018. 624 с.

16. Шиляев проти Російської Федераизї: Рішення Європейського суду з прав людини від 6 жовтня 2005 р. (заява № 9647/02). URL: https: / / europeancourt. ru/resheniya-evropejskogo-suda-narusskom-yazyke/shilyaev-protiv-rossiipostanovlenie-evropejskogo-suda (Jama звернення: 30.11.2020).

17. Матвєев проти Російської Федерациї : Рішення Європейського суду з 


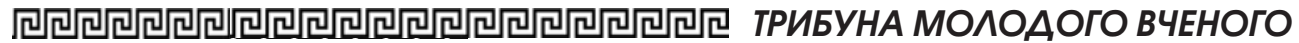

прав людини від 3 липня 2008 р. (заява № 26601/02). URL: http: / / docs.cntd.ru/ document/902169986 (дата звернення: 30.11.2020)

18. Наков проти Македонії: Рішення Європейського суду з прав людини від 24 жовтня 2002 р. (заява № 68286/01). URL: file: / / / C: / Users / $\%$ D0\%9C\%D O\% BO\% D $1 \% 80 \%$ DO $\%$ B $8 \%$ DO $\%$ BD $D$ 0\% B0 / Downloads /001-22799\% 20(1).pdf (дата звернення: 30.11.2020).

19. Свіргунець проти України Рішення Європейського суду з прав людини від 30 квітня 2020 р. (заява
№ 38262/10). URL: https: / / zakon.rada. gov.ua/laws/show/974_f11\#Text (Jama звернення: 30.11.2020).

20. Доповідь, схвалена Венеиійською Комісією Pади Європи на 86-му пленарному засіданні (Венеиія, 25-26 березня 2011 р.) «Верховенство права». Право Украӥни. 2011. № 10. С. 179-180.

21. Пономарьов проти України : Рішення Європейського суду з прав людини від 3 квітня 2008 p. (заява № 3236/03). URL: https: / / zakon.rada. gov.ua/laws/show/974_434\#Text (dama звернення: 30.11.2020). 